\title{
Consensus
}

Volume 38

Issue 2 Reformation: Then, Now, and Onward. Diverse

Article 15

Disputations Effectual Exposés

$12-1-2017$

\section{Ink Against the Devil: Luther and His Opponents}

David G. A. Pfrimmer

Follow this and additional works at: http://scholars.wlu.ca/consensus

Part of the Religion Commons

\section{Recommended Citation}

Pfrimmer, David G. A. (2017) "Ink Against the Devil: Luther and His Opponents," Consensus: Vol. 38 : Iss. 2 , Article 15.

Available at: http://scholars.wlu.ca/consensus/vol38/iss2/15

This Book Reviews is brought to you for free and open access by Scholars Commons @ Laurier. It has been accepted for inclusion in Consensus by an authorized editor of Scholars Commons@ Laurier. For more information, please contact scholarscommons@wlu.ca. 


\title{
Book Review
}

\author{
Ink Against the Devil: Luther and His Opponents \\ Harry Loewen \\ Waterloo: Wilfrid Laurier University Press, 2015
}

\begin{abstract}
$\mathrm{A}$ t the July 22, 2010 Assembly in Stuttgart, Germany, the Lutheran World Federation (LWF) Assembly unanimously adopted a statement "asking the Mennonites (i.e. Anabaptists) for forgiveness for past persecutions." ("Lutheran Take Historic Step in Asking for Forgiveness from Mennonites," LWF, 2010) For all the delegates from around the world, it was the most powerful moment of the Assembly. Yet for many, these events are largely unknown. Harry Loewen's Ink Against the Devil is timely and important contribution to the 500th commemoration of the Reformation in
\end{abstract}

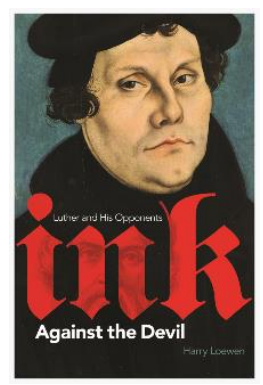
2017.

Many associate the Reformation as a singularly Lutheran and mainly theological event. Clearly Luther and theology were important. However, it would be more accurate to recognize it as an era of theological, social, economic and political turmoil with multiple reformation movements all pressing for change and all pursuing their own agendas. Karen Armstrong has described this era (c. 1500-2000) as the beginning of the "Great Western Transformation" (A Short History of Myth, 2005) Often the Reformation is portrayed simply as a struggle between a rebellious Luther and the Roman Catholic Church. It was not that simple. The Magisterial Reformation had support from princes, magistrates and city councils to implement their changes. The Counter-Reformation arose within the Roman Catholic Church to bring forward their own changes to stem the Lutheran movement. The Radical Reformation believed model Christian communities apart from the state were necessary. Loewen shows how 16th-century reformations were a messy, complicated and at times violent affair.

Loewen's Ink against the Devil: Luther and His Opponents provides a very helpful immersion into Luther's engagement with his opponents, most notably the radical wing of the Reformation. We would do well to remember that some of the most acrimonious and violent conflicts were not just between Lutherans and Catholics, but also when Catholics and Lutherans joined forces against the Anabaptists or when there were subsequent internecine battles among Protestants themselves. Loewen takes us into some of these theological conflicts that would spill out into broader public life.

Loewen begins by describing Luther's theological journey and his major writings. Key to understanding the conflict between Luther and the Anabaptists were two of his key theological convictions. These arose from Luther's search for a gracious God. The first was justification by grace alone (sola gratia) through faith alone (sola fide). Luther argued that it is only through Jesus Christ by grace alone and faith alone that a person could be saved. Loewen reduces this formulation in his discussion to sola fide but does assume the importance of grace for Luther. The second was Luther's appeal to the Word of God (i.e. Gospel) as the authouritative source (sola scriptura) for his theological conviction. Sola fide and sola scriptura are central to Loewen's diagnosis of the conflict between Luther and the radical reformers. While he might be accommodating in some matters, Luther would be uncompromising in his defense of sola fide. As Loewen points out, "For Luther, the doctrine 
of justification was of such importance that not to accept it was to blaspheme God and to repudiate the Christian religion." (Loewen, 2015, 284).

Loewen goes onto look at how these theological convictions impacted the way Luther engaged with various opponents and groups; the "Wittenberg radicals" like Karlstadt, Thomas Münster, the "Peasants Revolt," the humanist Erasmus, the papacy and the Jews. Luther did not see his opponents as people who disagreed with his ideas. To Luther this was the devil working through these people to undermine the gospel (sola fide). Luther believed this handiwork of the devil had to be excised from society. Based upon his own misguided logic, he felt justified in advocating the extreme measures he so tragically did. His descendants have been redressing the wreckage ever since.

Loewen is generous in describing Luther's relationship to the Anabaptists. Not to minimize their differences, Lutherans and Anabaptists share a lot in common. Anabaptists were inspired by Luther's concept of justification. Loewen points out that Luther was an important influence on Menno Simons "who accepted Luther's principle of justification by faith alone but believed that Lutherans were so one-side in teaching this doctrine that they neglected to stress the importance of Christians ethics." (Loewen, 2015, 157) For Luther, the Anabaptist's views smacked of "works righteousness." For Mennonites Luther's claim of justification alone revealed a lifeless faith short on discipleship and lacking a commitment to serving their neighbour. Loewen rightly points out that Luther and Melanchthon were concerned about faith active in love to neighbour. While works were not required for salvation, it did not allow Lutherans to do whatever they pleased. But the acrimony and incivility of times and the rigidity of Luther prevented this discussion.

Another key point for Loewen was their different views toward the state. Luther was one of the magisterial reformers who relied on the princes, magistrates, city councils (i.e. the state authourities) to secure the reforms and changes they were proposing. On the other side, Anabaptists felt Christian communities were to be set apart, separated from state's coercive power. The support from the governing authourities blinded Luther to the insights Anabaptists offered. Luther's views hardened after the "fanatical Anabaptists" sought to erect "their kingdom in Münster, Westphalia (1534-35)." (Loewen, 2015, 149) For Luther "To rebel against spiritual authourities when they are wrong is permissible and sometimes necessary, whereas to rebel against magistrates, the temporal authorities, is not allowed." (Loewen, 2015, 55) For Luther, "past radicalism, the 'peasant rebellions, and now Münster blinded Luther's eyes so that he saw nothing but evil in all Anabaptists." (Loewen, 2015, 157) As Loewen tragically reminds us, "Ironically, these more peaceful radicals believed what Luther believed ... (about Christians) suffering patiently rather than taking up arms against their oppressors." (Loewen, 2015, 157) In sanctioning these persecutions, Lutheran and Roman Catholic authourities, imprisoned and tortured thousands of Anabaptists and almost 3000 were executed for their beliefs.

Loewen also points out that Luther was tolerant of religious dissent in the early years when he was under threat but became intolerant in later years when "Lutheran Protestantism became the established religion of the realm ((Loewen, 2015, 201) Loewen argues that it was Anabaptists who "laid the foundation of religious liberty by insisting that church and state must be separate, that only believers were to be baptized, that Christians must reject all violence, and that the individual is primarily responsible to God and not to any human authority." (Loewen, 2015, 222) While Loewen's argument has a great deal of merit, there is a larger framework to consider. More broadly churches have contributed to 
this human rights debate and the formulation of some of the issues around religious liberty. For example, the Lutheran Frederick Nolde helped "in writing the religious freedom clause" in the Universal Declaration on Human Rights. As well, Mennonite Ernie Reghr and Project Ploughshares have led the development of an ecumenical convergence in Canada on "just policing" and the appropriate use of state force. Loewen does remind us that these developments do have their origins in these Reformation dynamics. But their origins are not quite so clear-cut. Various traditions have contributed by evolving and moderating their sixteenth century views.

If there were something I would have liked to seen included it would have been Loewen's thoughts about the future. Yes, Lutheran's have asked for forgiveness and Mennonites have extended it. What are the future theological implications for both traditions? Work is being done. For example, recently a team of Lutheran, Mennonite and Catholic theologians has been completing work on the question of "Baptism and Incorporation into the Body of Christ, the Church." (LWF, 20 September 2017) I believe Loewen has some ideas too that might have been included in this volume. In a chapter entitled, The Divine Comedy of a Reformation Principle: Luther, the Anabaptists, and Bonhoeffer on Sola Fide, (The Theology of Martin Luther, Egil Grislis, Woodlake Books, 1985) Loewen describes the irony of Dietrich Bonhoeffer's "reinterpretation of Luther" and justification in a more Anabaptist direction in his The Cost of Discipleship. This is a helpful perspective. Lutherans and Mennonites together will need to think more about this theological direction and other implications.

In his original book Luther and the Radicals (WLU Press, 1974), Loewen provided a very helpful typography of the various strands of the radical reformation (e.g. The Wittenberg Radicals, the Revolutionary Radicals, the Evangelical Anabaptists, the Revolutionary Anabaptists, and the Spiritualists, Antinomians, and Antitrinitarians.) In Ink Against the Devil Loewen develops his thesis without specifically referring to this earlier typography. I suspect this is because Mennonites themselves are moving on from this internal debate about the nature and diversity of the 16th-century Anabaptist movement. Nevertheless, Loewen's 1974 categories do offer helpful distinctions to understand the Radical Reformation, particularly for non-Mennonites.. It may be one reason why reviews of his earlier book "from non-Mennonite critics at the time were more positive that from Mennonite reviewers." (Loewen, 2015, xiii) Luther did not appreciate this diversity among Anabaptists. Mennonites just like Lutherans (and other traditions) have had many of their own internal conflicts. At the LWF Stuttgart Assembly, I remember one of the Mennonite speakers pointing out how his Mennonite community would need to reexamine their own stories in the light to the Lutheran action. He was referring to important place of the testimony of the martyrs during these persecutions in defining a Mennonite identity. Lutherans will have to review Luther's complicity and what that means as well.

Harry Loewen has provided an important contribution to healing the past divisions of the 16th century. He may have also provided a helpful introduction to how Lutherans and Mennonites can tell their stories about each other and about themselves in a new way. Reexamining our stories in churches will be increasingly important in our pluralistic, secular, culturally diverse and multifaith world. What have we learned about this journey in these last 500 years that might be instructive for dealing with our differences and recognizing our similarities? Religious leaders of all persuasions should be reading this book if for no other reason than it is a case study of where even the best theology and brilliant theologians can 
stumble, where an unwillingness to dialogue and work with each other leads to misunderstanding and tragedy, and where theological hubris can lead us to demonize others with serious consequences for generations.

David Pfrimmer

Professor Emeritus for Public Ethics

Waterloo Lutheran Seminary

Waterloo, Ontario 